\title{
Expression Analysis of Pyrenophora teres f. maculata-Responsive Loci in Hordeum vulgare
}

\author{
Yosra Habachi-Houimli ${ }^{1}$ \\ https://orcid.org/0000-0002-0208-9956
}

Mejda Cherif ${ }^{2}$

https://orcid.org/0000-0003-3856-0006

Charfeddine Gharsallah ${ }^{3}$

https://orcid.org/0000-0003-2548-0509

\section{Abdennour Sébéi ${ }^{4}$}

https://orcid.org/0000-0003-3410-0045

\section{Mohamed Makni ${ }^{1}$}

https://orcid.org/0000-0002-1034-0012

\section{Dhia Bouktila ${ }^{1,5^{\star}}$}

https://orcid.org/0000-0002-7360-5161

\begin{abstract}
1Université de Tunis El Manar, Faculté des Sciences de Tunis, Unité de Recherche UR11ES10 Génomique des Insectes Ravageurs des Cultures d'intérêt agronomique (GIRC), 2092, El Manar, Tunis, Tunisia; ${ }^{2}$ nnstitut National Agronomique de Tunisie (INAT), Tunis, Tunisia; ${ }^{3}$ Université de Tunis El Manar, Faculté des Sciences de Tunis, Laboratoire LR99ES12 de Génétique Moléculaire, Immunologie et Biotechnologie, 2092 El Manar, Tunis, Tunisia; ${ }^{4}$ Centre Régional de Recherches sur les Grandes Cultures de Béja (CRRGC), Université de Jendouba, Béja, Tunisia; ${ }^{5}$ Université de Jendouba, Institut Supérieur de Biotechnologie de Béja (ISBB), Tunisia.
\end{abstract}

Received: 2018.07.02; Accepted: 2019.07.08.

*Correspondence: dhia_bouktila2000@yahoo.fr; Tel.: +216-22569664 (D.B.)

\section{HIGHLIGHTS}

- We revealed the involvement of three barley loci in the defense response against Pyrenophora teres. f. maculata.

- These genes probably act as components of complex signaling pathways and would have cumulative effects.

- The studied genes were mapped on chromosomes $5 \mathrm{H}$ and $7 \mathrm{H}$ and phylogenetically characterized.

- These pathogen-responsive genes are promising for pathogen resistance engineering in barley and its relatives. 
Abstract: Pyrenophora teres $\mathrm{f}$. maculata is the causal agent of barley spot form net blotch (SFNB), a major stubble-borne disease in many barley-growing areas worldwide. In plants, the Nucleotide-Binding Site-Leucine-Rich Repeat (NBS-LRR) gene family functions in immunity against a variety of pathogens and pests. From a pre-established set of NBS-type resistance gene candidates, we have selected three candidate genes, HvNBS10, HvNBS72 and HvNBS85, to analyze their possible involvement in $P$. teres f. maculata resistance. The studied genes were mapped on chromosomes $5 \mathrm{H}$ and $7 \mathrm{H}$. Expression profiles using qRT-PCR, 48 hours after infection by $P$. teres. f. maculata, revealed that the transcription of all genes acted in the same direction (down-regulation) in both resistant and susceptible cultivars, although they showed a variation in transcript dosage. This result suggests that coordinated transcriptional responses of multiple barley NBS genes would be required to an efficient response against $P$. teres f. maculata. Moreover, the phylogenetic analysis revealed that the studied barley candidate $R$ genes were characterized by a high homology with the barley Nbs2-Rdg2a gene conferring resistance to the fungus Pyrenophora graminea, suggesting a common origin of $P$. graminea and $P$. teres resistance genes in barley, following pathogens evolution. The genes characterized in the present study hold potential in elucidating the molecular pathways and developing novel markers associated with SFNB resistance in barley.

Keywords: Spot form net blotch (SFNB); Nucleotide-binding site (NBS); Leucine-rich repeat (LRR); qRT-PCR; Hordeum vulgare.

\section{INTRODUCTION}

Plants are surrounded by a diverse range of pathogens. Against them, the first line of plant defense is non-host resistance, based on the recognition of a broad range of invariant pathogen/microbe-associated molecular patterns (PAMPs/MAMPs) by dedicated membrane-bound receptors, called pattern recognition receptors (PRRs), leading to the activation of pattern-triggered immunity (PTI) [1]. In the second phase, pathogen invasion may lead to the activation of effector-triggered immunity (ETI) that acts through cytoplasmic immune receptors responsible for the recognition of factors secreted by pathogens, which, in turn, activate downstream signaling pathways leading to a rapid local programmed cell death called hypersensitive response (HR). The defense response using cytoplasmic immune receptors is a well-known strategy characterized by specific interaction between disease resistance $(R)$ protein receptors of plants and corresponding avirulence (avr) gene products.

The most common $R$ gene class is represented genes encoding proteins containing a nucleotide-binding site (NBS) that is often associated with a leucine-rich repeats (LRR) domain [2]. The NBS domain is involved in signaling through the binding and hydrolysis of ATP and GTP and includes several highly conserved and strictly ordered motifs such as P-loop, kinase-2, Kinase-3a and GLPL [3]. The LRR domain typically consists of 20-30 amino acid repeats that are often involved in protein-protein interaction and, more precisely, binding to pathogen-derived molecules [4]. The LRR domain is thought to be the primary determinant of pathogen recognition specificity [5]. The NBS-LRR class of $R$ genes can be divided into two subfamilies: the TIR-NBS-LRR (TNL) proteins that contain an N-terminal Toll/Interleukin1 receptor domain (TIR) and the non-TIR-NBS-LRR, where a coiled-coil (CC) domain can be substituted to the TIR one, defining CC-NBS-LRR (CNL) proteins [2]. Transcriptome analysis is a powerful tool for studying the role of $R$ genes in disease resistance. Recently, the availability of draft or reference genomes for several plant species has enhanced the evaluation of expression levels of plant predicted genes. Resistance gene candidates (RGCs) encoding NBS-LRR proteins have been cloned from several plant species and many have co-localized with known resistance gene loci for both qualitative and quantitative resistance $[6,7]$. 
Barley, Hordeum vulgare L., is one of the world's oldest cultivated crops, spreading from its origin center in the 'fertile crescent' in the Middle East [8]. Since ancient times, barley has been used worldwide for animal feed and human food. The necrotrophic fungus Pyrenophora teres Drechs. is the causal agent of net blotch of barley, and exists in two forms, which, although morphologically indistinguishable under the microscope, can be differentiated by the symptoms observed on susceptible barley genotypes [9]. In fact, net form net blotch (NFNB), caused by $P$. teres $\mathrm{f}$. teres, is manifested by necrotic lesions with transverse and longitudinal striations, forming a net-like pattern of necrosis often accompanied by chlorosis [10], while spot form net blotch (SFNB) produces elliptical necrotic lesions surrounded by chlorosis [9]. In Tunisia, Cherif et al. [11] reported that net blotch is the most common disease of barley, occurring at high severity rates $(70-80 \%)$ in some regions of the country. Several studies have reported that resistance to $P$. teres could be controlled by either one or several genes, depending on the source of resistance, the plant development stage, and the pathotype used for testing [12]. From the six different genes conditioning resistance to net blotch [13], four have been mapped [14-16]. QTLs conferring $P$. teres $\mathrm{f}$. maculata resistance in seedling have been reported on chromosomes $2 \mathrm{H}, 3 \mathrm{H}, 4 \mathrm{H}$ and $7 \mathrm{H}[16,17]$; and those conferring resistance in adult stage on chromosomes $4 H, 5 H$ and $7 H[16]$. Wang et al. [18] reported that net blotch-resistance QTLs varied in effect, with large effects QTLs located on chromosome $7 H$. Despite these findings, there is little knowledge about the expression of defense responses against $P$. teres $f$. maculata, after infection of barley and none of the genes conferring barley resistance to $P$. teres has been identified at molecular level. Therefore, the aim of the present study was to investigate the potential to $P$. teres $\mathrm{f}$. maculata resistance among three $H$. vulgare candidate $R$ genes, through the analysis of their transcriptional activity.

\section{MATERIAL AND METHODS}

\section{Biological material and culture conditions}

Isolates of Pyrenophora teres f. maculata were collected from different agroecological regions in Tunisia, between January 2015 and January 2016. From infected barley leaves, spore samples were isolated with an eyelash under a binocular loupe. Single-spore cultures were prepared by transferring single spores to plates containing $200 \mathrm{ml}$ of V8 agar, $16 \mathrm{~g}$ of agar, and $3 \mathrm{~g} \mathrm{CaCO}_{3}$ per liter of $\mathrm{H}_{2} \mathrm{O}$. These plates were incubated at $21^{\circ} \mathrm{C}$ and $12: 12 \mathrm{~h}$ photoperiod under cool white light. Ten days later, conidia were harvested by adding $2 \mathrm{ml}$ of water to the plates and scraping the culture with a rubber spatula. This suspension was filtered through a double layer of cheesecloth to separate large mycelia fragments from conidia, and then the spore concentration was adjusted to $5.10^{4}$ conidia/ml, for inoculation.

\section{Inoculation of plants and resistance rating}

Five barley cultivars, 'Bowman', 'Rihane', 'HD35', 'Martin', 'Roho', were tested in order to evaluate their responses against Strain "Pt 01/2016" obtained, in January 2016, from the region of El-Fahs located in North Tunisia (36.37 N, 9.91 E). Cultivar HD29 was used as uninfected control. Initially, barley genotypes were sown (five to seven seeds) in plastic pots (25 cm diameter) filled with loamy-claysoil and grown in a greenhouse at $15-22^{\circ} \mathrm{C}$ at INAT, and inoculated 3 weeks later. The conidial suspension was sprayed onto the plants using a DeVilbiss atomizer. Treatments were replicated three times and were arranged in a randomized complete block design. Next, the plants were placed in a mist chamber at $18-22^{\circ} \mathrm{C}$ and $12: 12$ photoperiod, where the humidity was maintained near saturation. After a $72 \mathrm{~h}$ moist period, the plants were transferred to a growth chamber at $21-24^{\circ} \mathrm{C}$ and $12: 12 \mathrm{~h}$ photoperiod. At the 14th day following inoculation, the mycelia development was observed visually and plant responses to infection were rated on 1-10 disease reaction scales developed by Tekauz [19]. Genotypes showing lesions rated 5 or lower, which are restricted in size, are considered as resistant, while those with lesions rated above 5 , which continue to expand over time, are considered as susceptible. 


\section{Selection of barley candidate genes}

From the Whole Genome Shotgun Sequence assembly of barley cv. Bowman $(2,077,901$ contigs) (http://www.ncbi.nlm.nih.gov/Traces/wgs/?val=CAJX01), the NBS domain was tracked in translated contigs, using a Hidden Markov Model (HMM) procedure [20,21]. Ab initio gene prediction, using Fgenesh [22], followed by multiple computational analyses, enabled predicting 96 candidate genes, designated HvNBS1 through HvNBS96 [23]. Among these, three genes, namely HvNBS10, HvNBS72 and HvNBS85, are analyzed in the current study, for their possible involvement in $P$. teres resistance.

\section{Phylogenetic characterization of barley candidate $\boldsymbol{P}$. teres resistance genes}

Five reference barley resistance genes have been used for comparison. These include: (a) two non CNL barley $R$ genes; Rpg1 that confers resistance to stem rust, Puccinia graminis (GenBank accession ABK51311.1) [24], and the recessive barley mlo mutant allele conferring broad-spectrum resistance to powdery mildew, Erysiphe graminis f. sp. hordei (GenBank accession: CAB06083.1) [25]; (b) three CNL genes of the mildew locus $A(M L A)$, namely MLA10 (GenBank accession: AAQ55541.1) [26], MLA1 (GenBank accession: ACZ65507.1) [27] and MLA13 (GenBank: AAO16014.1) [28]. These three genes play a role in resistance to powdery mildew and it has been hypothesized that many variants of $M L A$ are different alleles rather than separate genes [29]. Further, we have included in the phylogeny: (c) the sequence of the Nbs2-Rdg2a gene responsive to inoculation by the leaf stripe disease on barley, caused by the seed-transmitted hemi-biotrophic fungus Pyrenophora graminea (GenBank ADK47522.1) [30]. The Arabidopsis thaliana RPM1 protein (GenBank accession CAA61131.1) [31] was used as outgroup.

Selected sequences were aligned using the program Muscle [32]. The phylogenetic tree was constructed using Molecular Evolutionary Genetics Analysis (MEGA) Version 5.0 [33] by employing the neighbor-joining (NJ) method with 1000 replicates for statistical reliability. All the other parameters were taken to the default settings.

\section{Total RNA extraction and cDNA synthesis}

Total RNA was extracted from the leaves of control, susceptible and resistant cultivars, $48 \mathrm{~h}$ after inoculation by strain "Pt 01/2016" of Pyrenophora teres. f. maculata, with a Trizol reagent (Invitrogen, Carlsbad, CA, USA). The following reagents were added into a sterile, nuclease-free tube on ice in the indicated order: $2.5 \mu \mathrm{g}$ total RNA, $2 \mu \mathrm{l}$ oligo (dT) primer, 11.5 $\mu \mathrm{l}$ nuclease-free water gently mixed, centrifuged at $2500 \mathrm{rpm}$ and incubated at $95^{\circ} \mathrm{C}$ for 2 min. The tube was then chilled on ice, spun down, and placed back on ice. $4 \mu$ reaction buffer (5X), $10 \mathrm{mM}$ dNTP mix, $0.5 \mu \mathrm{l}$ M-MLV Reverse Transcriptase, were mixed gently and centrifuged at $2500 \mathrm{rpm}$ for $5 \mathrm{~min}$. For gene-specific primed cDNA synthesis, samples were incubated for $60 \mathrm{~min}$ at $37^{\circ} \mathrm{C}$. Reaction was terminated by heating at $70^{\circ} \mathrm{C}$ for $5 \mathrm{~min}$. The synthesized cDNA was stored at $-20^{\circ} \mathrm{C}$.

\section{Quantitative Real-time PCR analysis}

Quantitative real-time PCR ( $\mathrm{RRT}$-PCR) was employed to validate the relative change in expression of genes in the resistant and susceptible cultivars, separately. Quantitative RT-PCR was performed in an ABI Prism 7000 sequence detection system (Applied Biosystems, USA). The conditions for qRT-PCR were as follows: initial denaturation at $95^{\circ} \mathrm{C}$ (10 min) followed by 40 cycles of $95^{\circ} \mathrm{C}(15 \mathrm{~s})$ and $60^{\circ} \mathrm{C}(1 \mathrm{~min})$. After the cycle was complete, melting curves analysis was performed at $60-95^{\circ} \mathrm{C}$ to verify the specificity of the amplicon for each primer pair. The barley actin gene [30] was used as a housekeeping gene. The specific primers used for qRT-PCR, listed in Table 1, were designed by Primer 3 software (http://simgene.com/Primer3). The $25 \mu \mathrm{l}$ reaction mixture contained $1 \mu \mathrm{l}$ of template cDNA, $10 \mu$ of Igreen QPCR master Mix-Rox (Biomatik, USA), and $10 \mu \mathrm{M}$ of forward and reverse primers. 
Table 1. Primers used in qRT-PCR analyses.

\begin{tabular}{|c|c|c|c|}
\hline Gene & Reference & Forward (5'-3') & Reverse (5'-3') \\
\hline HvNBS10 & & $\begin{array}{l}\text { CAAGGGGTTCAGCAAC } \\
\text { ATTT }\end{array}$ & GCTTTCCGTGCAAACAATTT \\
\hline HvNBS72 & $\begin{array}{c}\text { Primers } \\
\text { designed in the } \\
\text { present study }\end{array}$ & $\begin{array}{l}\text { TGGAAGGCCATTGAAG } \\
\text { AAAC }\end{array}$ & CTATGGTGGCACATTCGTTG \\
\hline HvNBS85 & & $\begin{array}{l}\text { CTCAGATGTGCCAGTG } \\
\text { CCTA }\end{array}$ & CATTCCATTATCCGCAGCTT \\
\hline Actin & $\begin{array}{l}\text { Bulgarelli et al. } \\
{[30]}\end{array}$ & $\begin{array}{l}\text { ATGTGGCCATCCAGGC } \\
\text { AGTGCTTT }\end{array}$ & $\begin{array}{l}\text { TGGTCTCATGGATTCCAGCA } \\
\text { GCTTCC }\end{array}$ \\
\hline
\end{tabular}

\section{Expression data analysis}

Relative expression of mRNA was calculated by the comparative CT method (Relative quantification, $R Q=2^{-\triangle \Delta C T}$ ) described by Livak and Schmittgen [34]. The relative expression level of each investigated gene was normalized to that of the actin control. Expression analysis was based on the $\log _{2}$ fold change of inoculated vs. control samples. Genes in resistant and susceptible plants were considered up or down-regulated if their $\log _{2}$ gene expression ratios were higher than 1 or smaller than -1 . DataAssist ${ }^{\mathrm{TM}}$ Software v3.0 (Applied Biosystems, USA) was used to generate a heatmap, reflecting the expression profiles. AnyGenes software (http://www.anygenes.com/anygenes/excel.php) was used to evaluate the $2^{-\triangle \Delta C T}$ value of the candidate genes under experimental conditions.

\section{RESULTS}

\section{Assessment of resistance to $P$. teres among barley genotypes}

Strain "Pt 01/2016" of $P$. teres. f. maculata used in this study produced abundant conidia in culture (Fig. 1a). Two weeks after inoculation, the tested varieties showed variable reactions to infection; the highest level of resistance was recorded in 'Bowman', while 'Rihane' was moderately resistant. 'HD35', 'Martin' and 'Roho' varieties were all susceptible (Fig. 1b).

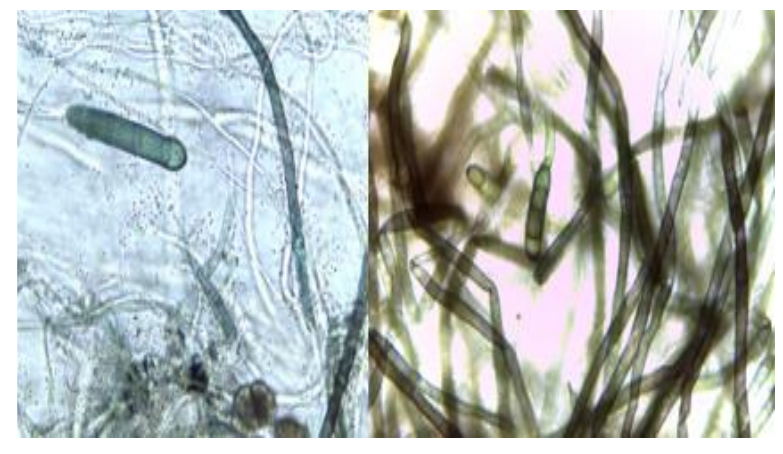

(a)

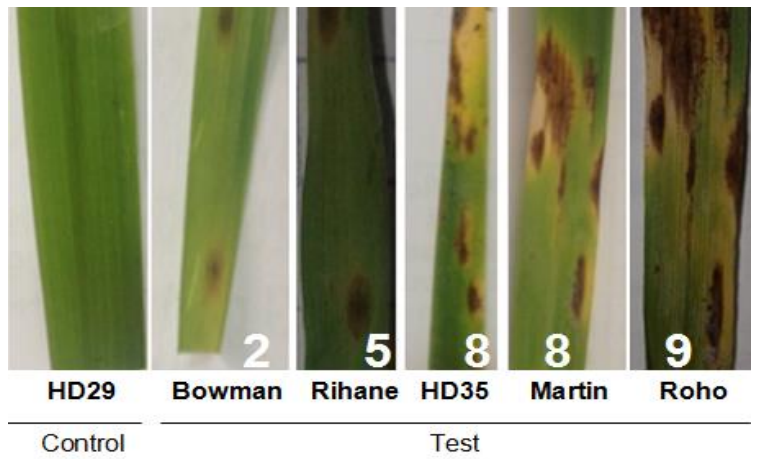

(b)

Figure 1. Reactions of five barley cultivars tested against Pyrenophora teres f. maculata. (a): Conidia and filaments of $P$. teres f. maculata; (b): Typical spot symptoms elicited on barley leaves by $P$. teres f. maculata and rating of cultivars using the system of Tekauz [19]. 


\section{Structural characterization and chromosomal mapping of barley candidate genes}

Three NBS-type $R$ gene candidates in barley, HvNBS10, HvNBS72 and HvNBS85, were selected for the present study, from a larger pool containing 96 NBS-type gene candidates previously predicted in barley cv. Bowman [23]. The candidate genes structures are illustrated in Table 2 (Part A). Comparing HvNBS10, HvNBS72, HvNBS85 genes, against the barley genomic high confidence genes (May, 2016) of the International barley sequencing consortium (IBSC) (https://webblast.ipk-gatersleben.de/barley_ibsc/), provided the results shown in Table 2 (Part B): HvNBS10 and HvNBS72 were mapped chromosome $7 H$, while HvNBS85 was located on chromosome $5 H$.

Table 2. Structural features and physical mapping of three barley candidate genes used in this study.

\section{A. Gene structure}

\begin{tabular}{lllllllllll}
\hline $\begin{array}{c}\text { Candidat } \\
\text { e gene }\end{array}$ & $\begin{array}{c}\text { Contig } \\
\text { accession } \\
\text { number } \\
\text { (Genbank) }\end{array}$ & $\begin{array}{c}\text { Chai } \\
\mathbf{n} \\
(+/-)\end{array}$ & From & To & From & To & $\begin{array}{c}\text { Coneding region } \\
\text { size }\end{array}$ & $\begin{array}{c}\text { Exo } \\
\text { ns }\end{array}$ & $\begin{array}{c}\text { Protein } \\
\text { length }\end{array}$ \\
\hline HvNBS10 & $\begin{array}{l}\text { CAJX01007550 } \\
8.1\end{array}$ & - & 1576 & 4253 & 2263 & 3888 & 1626 & 1 & 541 aa \\
HvNBS72 & $\begin{array}{l}\text { CAJX01086387 } \\
9.1\end{array}$ & - & 129 & 3916 & 222 & 3428 & 3207 & 1 & 1068 aa \\
HvNBS85 & $\begin{array}{l}\text { CAJX01028650 } \\
1.1\end{array}$ & - & 1696 & 5590 & 1916 & 5449 & 3534 & 1 & 1177 aa \\
\hline
\end{tabular}

B. Physical mapping

\begin{tabular}{clll}
\hline $\begin{array}{c}\text { Candidat } \\
\text { e gene }\end{array}$ & $\begin{array}{c}\text { Best matching } \\
\text { gene } \\
\text { (IBSC survey) }\end{array}$ & $\begin{array}{c}\text { TBLASTN data (\% } \\
\text { identity; identities; } \\
\text { e-value; score) }\end{array}$ & Chromosomal location \\
\hline HvNBS10 & $\begin{array}{l}\text { HORVU7Hr1G0 } \\
02260\end{array}$ & $86 ; 360 / 415 ; 0.0 ; 734$ & chr7H: $4360778-4419533$ \\
HvNBS72 & $\begin{array}{l}\text { HORVU7Hr1G0 } \\
26360\end{array}$ & $99 ; 1066 / 1068 ; 0.0 ; 2157$ & chr7H: 45224923-45229866 \\
HvNBS85 & $\begin{array}{l}\text { HORVU5Hr1G0 } \\
06710\end{array}$ & $98 ; 1161 / 1179 ; 0.0 ; 2313$ & chr5H: 12035416-12041558 \\
\hline
\end{tabular}

\section{Expression profiles of $\boldsymbol{H}$. vulgare candidate genes upon $\boldsymbol{P}$. teres infection}

The transcriptional activity of HvNBS10, HvNBS72, and HvNBS85, upon infection by $P$. teres. f. maculata, was examined by qRT-PCR. The most contrasted $H$. vulgare genotypes, namely resistant 'Bowman' and susceptible 'Roho', were challenged with the pathogen, and the expression of the four studied genes, following inoculation, was compared with 'HD29' ininoculated leaves.

For all genes, a differential expression (DE) was evident under infection by $P$. teres (Fig. 2). HvNBS10, HvNBS72 and HvNBS85 were all significantly downregulated, either in susceptible 'Roho' or in resistant 'Bowman', in comparison to the control. Nevertheless, a difference in transcript abundance was noted when comparing resistant and susceptible cultivars (Fig. 2), suggesting that these genes contribute to resistance through a transcript dose-sensitive mode. We speculate that these genes would possess common regulatory variants, such as miRNAs, that could potentially function as genetic expression modifying factors by modulating transcript stability. These data provide important insights into how barley may express resistance to infection by $P$. teres. f. maculata. 


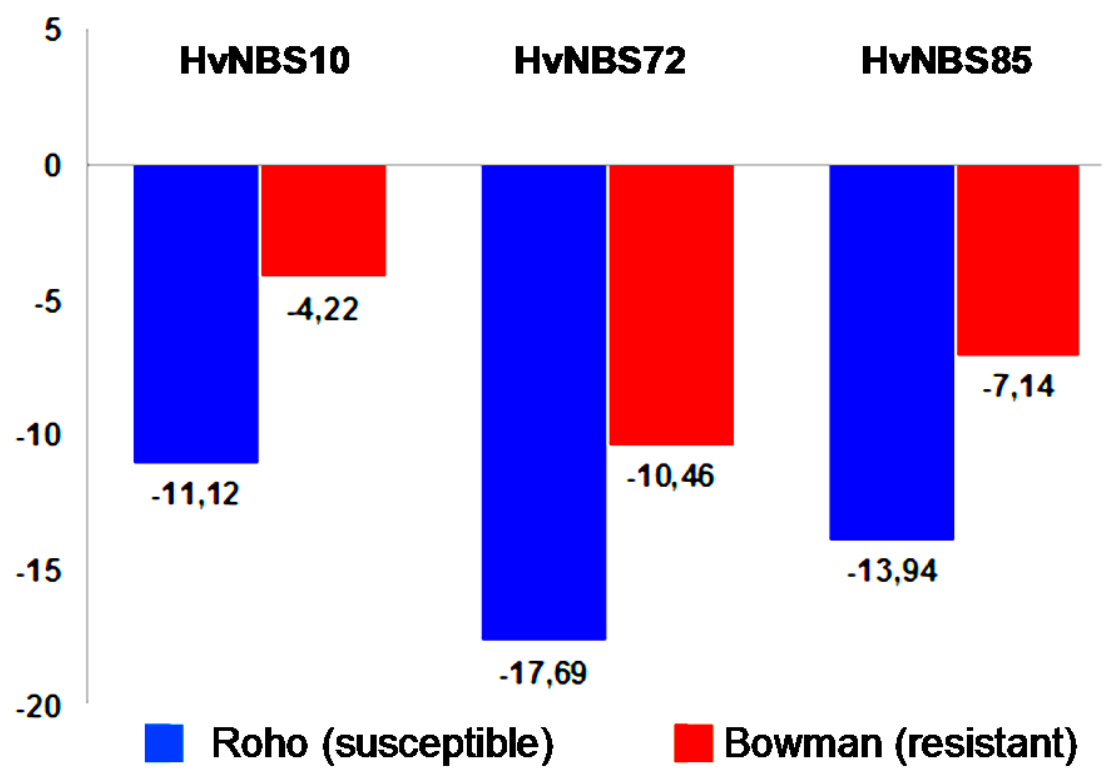

Figure 2. Relative transcript level of three HvNBSs obtained from quantitative real time PCR analysis in different cultivars of barley, following infection by Pyrenophora teres f. maculata.

Bar charts represent the values of $\log _{2}\left(2^{-\Delta \Delta C T}\right)$ for selected genes in resistant and susceptible cultivars. The barley actin gene was used as internal reference gene for data normalization.

\section{Comparative phylogeny}

Phylogenetic analysis by the $\mathrm{NJ}$ method was conducted in order to determine the relationships among the studied Pyrenophora teres f. maculata resistance gene candidates (RGCs) and a set of $R$ genes from barley. Based on relationships in the tree (Fig. 3), we could distinguish three clusters: Cluster (A) grouped the studied RGCs, HvNBS10, HvNBS72 and HvNBS85, that were characterized by their highest homology with the barley gene NBS2-Rdg2a (GenBank accession: ADK47522.1), conferring resistance to the fungus Pyrenophora graminea, as reported by Bulgarelli et al. [30]; cluster (B) included the three NBS-class genes MLA1, MLA10 and MLA13; and cluster (C) contained non NBS genes mlo and Rpg1. The barley gene NBS2-Rdg2a has been mapped on the short arm of chromosome 7HS [35]. Therefore, our results strongly suggest a common origin of $P$. graminea and $P$. teres resistance genes in barley, through duplication and diversifying evolution, following pathogen evolution. 


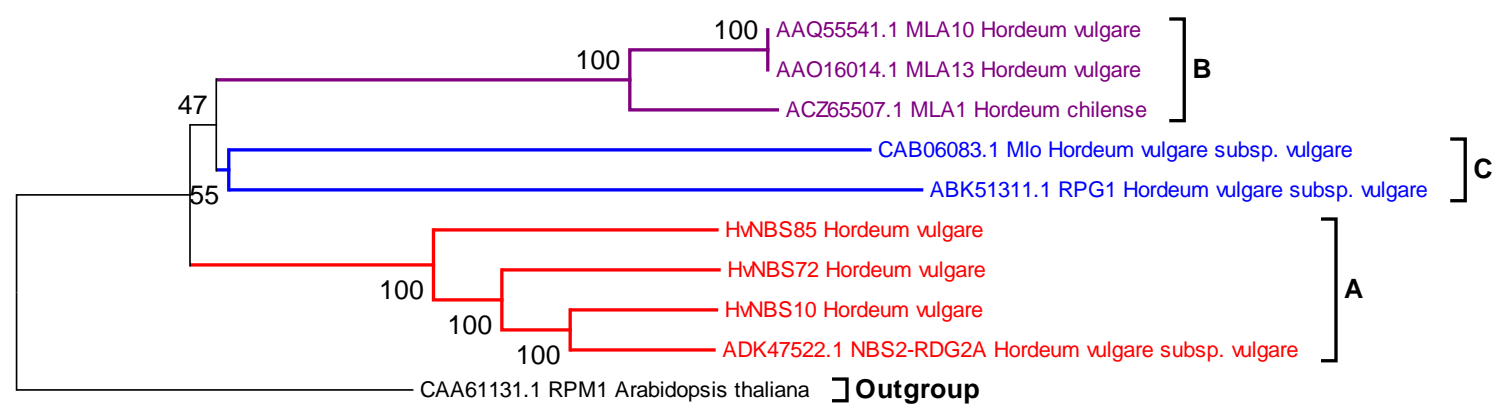

20

Figure 3. Neighbor-joining phylogenetic tree including HvNBS10, HvNBS72, HvNBS85 and other resistance proteins from barley.

Numbers on the nodes indicate bootstrap percentages. The A. thaliana RPM1 protein (CAA61131.1) was used as outgroup. Shown are the barley $(H$. vulgare) powdery mildew resistance proteins MLA1, MLA10 and MLA13 (CC-NBS-LRRs), the barley powdery mildew resistant allele mlo, the barley stem rust resistance gene Rpg1 (non NBS-LRRs) and the disease resistance protein NBS2-RDG2A encoded by the NBS2-RDG2A gene responsive to the leaf stripe disease, Pyrenophora graminea, in barley.

\section{DISCUSSION}

The present study revealed the probable involvement of three barley loci in the host defense response against $P$. teres f. maculata. The transcription of HvNBS10, HvNBS72 and HvNBS85 acted in the same direction in both resistant and susceptible cultivars, with a variation in transcript dosage. A significant number of investigations have already reported the key role played by such a coordinated functioning of different NBS-LRR loci, for a successful biotic stress resistance. In fact, plant NBS-LRR proteins act through a network of signaling pathways and induce a series of plant defense responses, such as activation of an oxidative burst, calcium and ion flows, induction of pathogenesis-related genes, and the hypersensitive response [36]. At least three independent, genetically defined signaling pathways in Arabidopsis are induced by NBS-LRR proteins [37]. Therefore, a large number of host genes may take part in resistance signaling and defense processes, and they may interact in a complex manner. In addition to resistance genes with cumulative effects, gene expression is often modulated, at the transcriptional level, by gene repressor/activator proteins that bind transcription factors, and, at the post-transcriptional level, by non coding microRNAs (miRNAs) that are able to modulate the expression in both normal and pathological conditions, by inhibiting translation or inducing degradation of transcripts [38-40]. Therefore, in order to efficiently develop resistant varieties, it is imperative to have a deeper knowledge of changes in the mRNA, protein, cellular metabolites and regulatory miRNAs after barley infection by $P$. teres. f. maculata, which will lead to a greater understanding of the plant-pathogen interaction and enhance the efficiency of the development of new resistant genotypes.

Importantly, pathogen-responsive NBS-LRR genes identified in present study are promising to be used as candidate genes for engineering pathogen resistance in barley and related crop species, such as wheat, where $P$. teres, the causal agent of barley net blotch, has been already detected [41]. Notably, several $R$ genes have been already used as transgenes within related species from the same family, such as the pepper Bs2 gene, an NBS-LRR gene providing resistance in susceptible pepper, tomato and Nicotiana benthamiana against the bacterial spot disease caused by the bacterium Xanthomonas campestris pv. vesicatoria (Xcv) $[42,43]$. Further, transient expression of Bs2 induced plant defense mechanisms in lemon against Xanthomonas citri subsp. citri (Xcc), causing citrus canker [43].

In conclusion, our study reports candidate genes that may play a role in resistance of barley and eventually other Poaceae to Pyrenophora species and increases our 
understanding of the molecular mechanisms involved in barley defense against necrotrophic fungi.

Funding: This research was funded by the Tunisian Ministry of Higher Education and Scientific Research.

Acknowledgments: The authors thank Pr. Hatem Fakhfakh (Laboratory LR99ES12, Faculty of Sciences of Tunis), for his logistic assistance in providing qRT-PCR facility.

Conflicts of Interest: The authors declare no conflict of interest. The funders had no role in the design of the study; in the collection, analyses, or interpretation of data; in the writing of the manuscript, or in the decision to publish the results.

\section{REFERENCES}

1. Jones JDG, Dangl JL. The Plant Immune System. Nature. 2006; 444:323-9.

2. Dangl JL, Jones JD. Plant pathogens and integrated defense responses to infection. Nature. 2001:411:826-33.

3. Belkhadir Y, Nimchuk Z, Hubert DA, Mackey D, Dangl JL. Arabidopsis RIN4 negatively regulates disease resistance mediated by RPS2 and RPM1 downstream or independent of the NDR1 signal modulator and is not required for the virulence functions of bacterial type III effectors AvrRpt2 or AvrRpm1. Plant Cell. 2004; 16:2822-35.

4. Kobe B, Kajava AV. The leucine-rich repeat as a protein recognition motif. Current Opinion in Structural Biology. 2001; 11:725-32.

5. Ellis JG, Lawrence GJ, Dodds PN. Further analysis of gene-for-gene disease resistance specificity in flax. Molecular Plant Pathology. 2007; 8:103-9.

6. Kang YJ, Kim KH, Shim S, Yoon MY, Sun S, Kim MY, Van K, Lee S-H. Genome-wide mapping of NBS-LRR genes and their association with disease resistance in soybean. BMC Plant Biology. 2012; 12:139. doi:10.1186/1471-2229-12-139.

7. Lozano R, Ponce O, Ramirez M, Mostajo N, Orjeda G. Genome-Wide Identification and Mapping of NBS-Encoding Resistance Genes in Solanum tuberosum Group Phureja. PLoS ONE. 2012;7(4): e34775. doi: 10.1371/journal.pone.0034775.

8. Nevo E. Origin, evolution, population genetics and resources for breeding of wild barley, Hordeum spontaneum, in the Fertile Crescent. In: Barley: Genetics, Biochemistry, Molecular Biology and Biotechnology. Shewry PR, editor. Wallingford: CAB International; 1992.

9. McLean MS, Howlett BJ, Hollaway GJ. Epidemiology and control of spot form of net blotch (Pyrenophora teres f. maculata) of barley: a review. Crop Pasture Science. 2009; 60:303-15.

10. Mathre DE. Compendium of Barley Diseases. 2nd ed. St. Paul (USA): American Phytopathological Society; 1992.

11. Cherif M, Harrabi M, Morjane H. Distribution and importance of wheat and barley diseases in Tunisia, 1989 to 1991. Rachis. 1994; 13:25-34.

12. Afanasenko O, Filatova O, Mironenko N, Terentieva I, Kopahnke D, Manninen O. Genetic resources of barley resistance to net blotch. In: Spunar J, Janikova J, editors. Proceedings of the 9th International Barley Genetics Symposium; 2004; Brno (Czech Republic): [publisher unknown]; 2004. p. 615-20.

13. Chelkowski J, Tyrka M, Sobkiewicz A. Resistance genes in barley (Hordeum vulgare L.) and their identification with molecular markers. Journal of Applied Genetics. 2003; 44:291-309.

14. Williams KJ, Lichon A, Gianquitto P, Kretschmer JM, Karakousis A, Manning S, et al. Identification and mapping of a gene conferring resistance to the spot form of net blotch (Pyrenophora teres f. maculata) in barley. Theoretical and Applied Genetics. 1999; 99:323-7.

15. Manninen O, Kalendar R, Robinson J, Schulman AH. Application of BARE-1 retrotransposon markers to the mapping of a major resistance gene for net blotch in barley. Molecular and General Genetics. 2000; 264:325-34.

16. Williams K, Cheong J, Scott L, Butt M, Wallwork H. Determining the genetics of leaf scald and spot form of net blotch resistance using molecular markers. In: Spunar J, Janikova J, editors. Proceedings of the 9th International Barley Genetics Symposium. Brno (Czech Republic): [publisher unknown]; 2004. p. 754-8. 
17. Molnar SJ, James LE, Kasha KJ. Inheritance and RAPD tagging of multiple genes for resistance to net blotch in barley. Genome. 2000; 43:224-31.

18. Wang X, Mace ES, Platz GJ, Hunt CH, Hickey LT, Franckowiak JD, et al. Spot form of net blotch resistance in barley is under complex genetic control. Theoretical and Applied Genetics. 2015; 128:489-99.

19. Tekauz A. A numerical scale to classify reactions of barley to Pyrenophora teres. Canadian Journal of Plant Pathology. 1985; 7:181-3.

20. Bouktila D, Khalfallah Y, Habachi-Houimli Y, Mezghani-Khemakhem M, Makni M, Makni H. The NBS-containing protein gene family in the Triticeae tribe. Genetics and Molecular Biology. 2014; 37:598-610.

21. Bouktila D, Khalfallah Y, Habachi-Houimli Y, Mezghani-Khemakhem M, Makni M, Makni H. Full-genome identification and characterization of NBS-encoding disease resistance genes in wheat. Molecular Genetics and Genomics. 2015; 290:257-71.

22. Salamov A, Solovyev V. Ab initio gene finding in Drosophila genomic DNA. Genome Research. 2000; 10:516-22.

23. Habachi-Houimli $Y$, Khalfallah $Y$, Mezghani-Khemakhem M, Makni H, Makni M, Bouktila D. Genome-wide identification, characterization, and evolutionary analysis of NBS-encoding resistance genes in barley. 3 Biotech. 2018; 8:453. doi:10.1007/s13205-018-1478-6.

24. Mirlohi A, Brueggeman R, Drader T, Nirmala J, Steffenson BJ, Kleinhofs A. Allele sequencing of the barley stem rust resistance gene Rpg1 identifies regions relevant to disease resistance. Phytopathology. 2008; 98:910-8.

25. Buschges R, Hollricher K, Panstruga R, Simons G, Wolter M, Frijters A, Van Daelen R, Van der Lee T, Diergaarde P, Groenendijk J, Topsch S, Vos P, Salamini F, Schulze-Lefert P. The barley Mlo gene: a novel control element of plant pathogen resistance. Cell. 1997; 88:695-705.

26. Halterman DA, Wise RP. A single-amino acid substitution in the sixth leucine-rich repeat of barley MLA6 and MLA13 alleviates dependence on RAR1 for disease resistance signalling. The Plant Journal. 2004; 38:215-26.

27. Seeholzer S, Tsuchimatsu T, Jordan T, Bieri S, Pajonk S, Yang W, Jahoor A, Shimizu KK, Keller $B$, Schulze-Lefert P. Diversity at the Mla powdery mildew resistance locus from cultivated barley reveals sites of positive selection. Molecular Plant-Microbe Interactions. 2010; 23:497-509.

28. Halterman DA, Wei F, Wise RP. Powdery mildew induced Mla mRNAs are alternatively spliced and contain multiple upstream open reading frames. Plant Physiology. 2003; 131:558-67.

29. Shen Q-H, Zhou F, Bieri S, Haizel T, Shirasu K, Schulze-Lefert P. Recognition specificity and RAR1/SGT1 dependence in barley Mla disease resistance genes to the powdery mildew fungus. Plant Cell Online. 2003; 15:732-44.

30. Bulgarelli D, Biselli C, Collins NC, Consonni G, Stanca AM, Schulze-Lefert P, Vale G. The CC-NB-LRR-type Rdg2a resistance gene confers immunity to the seed-borne barley leaf stripe pathogen in the absence of hypersensitive cell death. PLoS ONE. 2010;5:E12599. doi: 10.1371/journal.pone.0012599.

31. Grant MR, Godiard L, Straube E, Ashfield T, Lewald J, Sattler A, Innes RW, Dangl JL. Structure of the Arabidopsis RPM1 gene enabling dual specificity disease resistance. Science. 1995;69(5225):843-6.

32. Edgar RC. MUSCLE: multiple sequence alignment with high accuracy and high throughput. Nucleic Acids Research. 2004;32(5):1792-7. doi:10.1093/nar/gkh340.

33. Tamura K, Peterson D, Peterson N, Steecher G, Nei M, Kumar S. MEGA: Molecular Evolutionary Genetics Analysis using maximum likelihood, evolutionary distance, and maximum parsimony methods. Molecular Biology and Evolution. 2011; 28:2731-9.

34. Livak KJ, Schmittgen TD. Analysis of relative gene expression data using realtime quantitative PCR and the 2(-Delta Delta C(T)) Method. Methods. 2001; 25:402-8.

35. Tacconi G, Cattivelli L, Faccini N, Pecchioni N, Stanca AM, Valé G. Identification and mapping of a new leaf stripe resistance gene in barley (Hordeum vulgare L.). Theoretical and Applied Genetics. 2001; 102:1286-91.

36. Belkhadir Y, Subramaniam R, Dangl JL. Plant disease resistance protein signaling: NBS-LRR proteins and their partners. Current Opinion in Plant Biology. 2004; 7:391-9. 
37. Glazebrook J. Genes controlling expression of defense responses in Arabidopsis-2001 status. Current Opinion in Plant Biology. 2001; 4:301-8.

38. Rodrigues SP, Lindsey GG, Fernandes PMB. Biotechnological approaches for plant viruses resistance: from general to the modern RNA silencing pathway. Brazilian Archives of Biology and Technology. 2009; 52:795-808.

39. Habachi-Houimli Y, Khalfallah Y, Makni H, Makni M, Bouktila D. Large-scale bioinformatic analysis of the regulation of disease resistance NBS gene family by microRNAs in Poaceae. Comptes Rendus Biologies. 2016; 339:347-56. doi: 10.1016/j.crvi.2016.05.011.

40. Bouallègue M, Bouktila D, Mezghani-Khemakhem M, Capy P, Makni M. In Silico Identification of MicroRNAs with B/CYDV Gene Silencing Potential. Brazilian Archives of Biology and Technology. 2016;59: e16160450. doi:10.1590/1678-4324-2016160450.

41. Mikhailova LA, Ternyuk IG, Mironenko NV. Pyrenophora teres, an agent causing wheat leaf spot. Microbiology. 2010; 79:561-5.

42. Hulbert SH, Webb CA, Smith SM, Sun Q. Resistance gene complexes: evolution and utilization. Annual Review of Phytopathology. 2001; 39:285-312.

43. Sendín LN, Filippone MP, Orce IG, Rigano L, Enrique R, Peña L, Vojnov AA, Marano MR, Castagnaro AP. Transient expression of pepper Bs2 gene in Citrus limon as an approach to evaluate its utility for management of citrus canker disease. Plant pathology. 2012; 61:648-57.

(C) 2018 by the authors. Submitted for possible open access publication under the terms and conditions of the Creative Commons Attribution (CC BY NC) license (https://creativecommons.org/licenses/by-nc/4.0/). 